\title{
LIFE CYCLE OF A WINE BRAND
}

\author{
Viktoriia PAZIUK', \\ Chernihiv National University of Technology, Ukraine
}

\begin{abstract}
The aim of the work is to determine the life cycle of the wine brand, the development of ways to improve its effectiveness at different stages of the life cycle. Being scientifically informed of the existence of the life cycle of the brand allows modern enterprises to enhance their competitive position in the market and take advantage of the acquired differences in order to attract more attention from consumers. Methods. The study is based on scientific methods of research of economic phenomena: the dialectic, abstract logical (in the exercise of theoretical generalizations to the definition of the concept of «life cycle of the perpetrator of the brand), a scientific abstraction, comparison and ordering (the study of factors influencing the life cycle of the perpetrator of the brand and the factors influencing a choice of products for consumers), statistical and problem-chronological (the study of the requirements of the brand in a changing consumer preferences), logical generalization (in determining the social and ethical functions guilty brand). Results. The stages of the life cycle of the wine brand, which take into account its characteristics and form its social and ethical functions. Describing the requirements for the wine brand in the changing tastes and preferences of consumers. Specification of wine promotion of the brand in an increasingly competitive environment. Preconditions have been set for a new wine brand. The practical significance. The brand always increases the value of the product and its entry into new markets, as well as reduces the time to attract consumers. Possibility to ensure the growth of the brand in a declining market; building market share in a highly competitive environment; marketing innovative products in order to create a new sales strategy. After all, to gain and maintain the popularity of a certain product, one must personalize it with giving associations and a way to provide it with distinctive features. Only then the product will cause its strong commitment and provide the expected profit. A brand contributes to an adequate instant reaction of manufacturers and distributors of products to internal and external challenges in a dynamic shift in the consumer market and increases competition. The value/ originality. Modern scientific studies increasingly gain urgency of development, existence and determination of characteristics of the brand life cycle. However, given specificity of the wine industry, the coverage of this issue in the literature requires constantly new and innovative approaches to problem-solving efficiency of the brand. The article explores and describes factors that affect the life cycle of the wine brand management that provides gain competitive advantages in certain stages and allows to extend the brand in the face of increasing competition.
\end{abstract}

Key words: brand, wine products, competition, life cycle, creating, wine brand, social and ethical function, factors value, consumer, idea, consumers' tastes and preferences.

JEL Classification: M30, M31, M39

\section{Introduction}

In a market environment for an effective response to competitive pressures a manufacturer must possess effective competitive advantages. Under these circumstances, the formation of a brand is extremely important. To keep the planned sales volume of wine production it is important to identify and analyze a life cycle brand features. The brand life cycle is a concept more generalized and powerful than the product life cycle. The duration of the brand existence is determined with the length of the brand commercial success of the the enterprise production program, which may consist of a plurality of kinds of the product life cycle, the time of which implementation do not match. In the process of the enterprise functioning total volume of sales is ensured with maximum of sales of a certain product the life cycle of which is at the stage of saturation. This creates the effect of a successful company in a competitive environment (Zozulov, 2004).

If an irreversible decline in sales takes place enterprises create conditions for the decline of the brand and its exit from the market. If the enterprise production program consists of one or two products, the life cycle of the brand can be commensurated with the product life cycle. In this case, the life cycle of the brand concept turns to be individual for a single product or service. Scientifically

Corresponding author:

${ }^{1}$ Department of Finance, Banking and Insurance, Chernihiv National University of Technology.

E-mail: vikalazarenko@rambler.ru 
based subsistence of a brand life cycle allows modern enterprises to strengthen their competitive position in the market and use acquired differences to attract more consumers' attention.

In modern scientific studies the developments concerning the existence and determining of characteristics of the brand life cycle are increasingly gaining relevance. The articles of domestic and foreign scientists and brand managers: Zozuliov O. Dligach A. Fedoriv A. Jones, D., B. Pustotin, D. Ohilvi, N. Klyayn, D. Traut, S. Pronin investigate and describe the factors affecting the wine brand life cycle, the management of which provides gaining competitive advantage at certain stages and allows to extend the brand in the increasing competition (Jones, 2005, Dligach, 2011, Fedoriv, 2013, Pustotin, 2015, Trout, 2012).

But taking into account the specificity of the wine sector, the issue of domestic literature highlights is incomplete and constantly needs new and innovative approaches to problem solving of the wine brand effectiveness. The main goal of this work is to determine the life cycle of the wine brand, develop ways to improve its effectiveness at different stages of the life cycle.

\section{Features of the wine brand life cycle}

The consumer selects the product on an emotional level and activity of the company is based on the implementation of a technology aimed at producing high quality products as the basis of introducing a brand, it is the presence of the brand that will allow the manufacturer to build an emotional connection with the consumer. Many manufacturers of wine products are seeking standard solutions with predictable results.

But creating and promoting of the wine brand is always a risk as consumers' emotions can be very different. The correct system for creating brand is the main secret of success for any manufacturer. Innovative methods must be at its core. Creating a wine brand, especially under current difficult conditions, foresees significant investments. Bases for creating and promoting a wine brand are the same as in other types of business: understanding market demands and anticipating consumers' wishes, knowing the benefits and features of the product - its strengths and weaknesses, and also being informed about the products of your competitors.

The main feature of work with wine products is a differentiated approach to a particular market segment. The effectiveness of the wine brand is significantly enhanced when the brand is built on the right identified trends and forecasts of the production program and reflects the wishes, preferences and tastes of consumers (fig. 1).

Stages of the wine brand life cycle have the following features:

- on the stage of development of the brand it is necessary to analyze the market, to study competitors' experience and to segment customers with identifying their key needs and desires, to create a wine product positioning, to develop a system of visual identity of the brand, to launch a series of communication campaigns to come up with a name, to elaborate packaging, label and a system of visual identity. It is very important that the manufacturer before the introduction of the brand to the market would be ready to have clear and complete understanding of the situation in logistics, seasonality of consumption, seasonal promotional activity, knowledge of competitors' activity, knowledge of the target audience and others;

- the stage of introduction of the brand in the market is the most difficult and risky task. This stage is charecterized with instability, costs, even losses for the manufacturer. At the stage of implementation of the brand it is important to pay attention to the preliminary key factors: the right moment, a high-quality product, distribution, knowledge of the target audience, a clear message and clearly deliberated advertising strategy. New brands that started in the market during the period of decreasing leaders' activity tend to occupying rapidly a significant share, and helding it for several years. The brand affects the perception of the product, the competition, facilitating the entry and negotiations with retailers, helping to create fashion. Thanks to the right implementation of the brand a consumer becomes less sensitive to the price and the brand suffers much less pressure from the innovation processes; - the stage of growth of the brand the brand is characterized with active introduction of the brand to the market, a powerful advertising support, increasing spending on marketing activities. The intensive growth may be extended

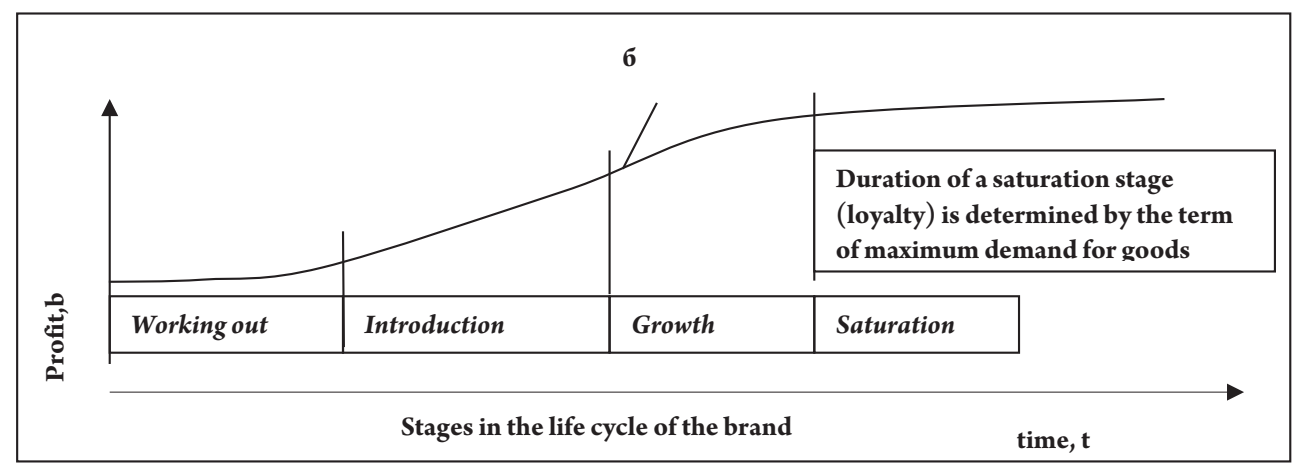

Fig. 1. The life cycle of the wine brand 
by additional stimulation of consumers through a variety of marketing tools, such as finding new distribution channels, expanding segments.

- the stage of saturation (loyalty) is usually much longer than the previous stages, and the producer, usually seeks to extend it further. The phase of saturation is defined by the term of product presence in the market (Pyankova, 2012). Important tools of support at saturation stage are: an efficient distribution system, good marketing, competitive product price, innovative method of quality control, narrow and precise positioning.

\section{Factors that affect the wine brand lifetime}

The key strategic factors that influence the wine brand life cycle are the product life cycle and the market life cycle. Thus, from the first steps of brand promoting it is important to predict the lifetime of the product and the market. Ukrainian wine market in recent years has undergone a number of changes as for the European values and preferences. The share of wine production in Ukraine accounts for about $10 \%$ of total consumption of alcohol. At the same time, in European countries in the structure of drinking wine occupies $70-80 \%$, which demonstrates the potential of growth of the Ukrainian wine market. The reason is that all products go through similar stages of public recognition.

As the society begins to accept and support innovation, new product increases, and ultimately reaches maturity. When there is a better alternative product or when at changing social benefits, sales volume is directed on the decline, the conditions for transition to the final stage of the life cycle - «recession $\gg-$ are created. With brand it is possible to provide growth on a falling market; increasing the market share under conditions of high competition; joining the market with innovative products in order to develop new marketing strategies. Firstly, for effective communication it is necessary to provide important, understandable and attractive idea. Secondly, there must be adequate resources for the campaign. Thirdly, the success rate increases dramatically if you join a new market segment. It is also necessary to provide the right choice of qualitative raw materials. The consideration of these factors affects the effectiveness of the wine brand under conditions of increasing competition.

\section{Wine brand in the increasing competition}

Today in the domestic market of wine production there is an increasing competition from other states producers that requires from local wineries efficient activities to improve competitiveness. It also has its explanations: difficult economic conditions in the industry, reducing the commodity market, increasing of restrictions by the state. Currently, Ukrainian producers have difficulties in increasing competitiveness because the competitive advantage primarily depends on the quality of wine production and consumers' confidence. Under current difficult conditions, domestic producers face a choice: to roll advertising activity and leave the market positions or to strengthen their positions and reduce the distance with competitors. In addition, the Ukrainian market of alcoholic beverages should consider the indirect competition among other types of alcoholic beverages.

As the practice showed manufacturers that build relationships with consumers on the values of the brand are stronger and more profitable than others. Consequently, the domestic brands to ensure the competitiveness of products are destined to radical, bright, brave decisions and are required to be different from existing brands and surprise by their originality and attractiveness. Consumers appeal to the brand that is increasing its popularity.

\section{Factors influencing the choice of products by consumers}

Factors influencing the choice of consumers of products include: high quality, commitment to the brand, the interest for something new. Another fact that influences consumers' choice is the price. Since the mass consumer in Ukraine has a relatively weak purchasing power, it also affects the choice of wine beverages. Nowadays, European countries are actively promoting a healthy lifestyle and no less actively promoting natural products. Thus, social and ethical factors also encourage consumers to opt for a particular brand. Socio-ethical factors include consumption culture and social status of the consumer. Consumer's behavior is influenced with such reference groups as family, social status, and his personal characteristics, especially such as age, family life cycle stage, occupation, economic condition, personality type and presentation of himself (Aleshin, 2013).

In Ukraine, there is a very weak culture of wine consumption, only a small number of consumers of alcoholic beverages prefer wine (Fedoriv, 2015). That is why the wine brand must constantly attract new customers, rather than focusing on consumers who gave their preference to other alcoholic drinks for many years. Thus, promoting the wine brand is more efficient among consumers above 21 . For successful branding one must use a set of tools based on the demonstration of product use, intake, the benefits of the product, using rules and standards, terms of consumption, product information, how to feed and ritual consumption.

If measures relating to the creation and promotion of the wine brand in the first place will transmit the emotional essence of the brand and will not be too focused on the qualitative and quantitative characteristics of the product, only in this case it will be a success and provide the explosive sales growth (Saveliev, 2011). It is important to build a brand that will work with the expectation of long term. Selling wine in the market requires a fundamentally different approach. Traditions determine demand and impose supply. Today there is a stereotype of consumer's thinking, formed in Soviet times.

Many Ukrainian consumers are more focused on the external perception: the desire for luxury and prestige is 
manifested even among ordinary customers. Unfortunately, today, some manufacturers offer mass consumer a product of low quality in an expensive package and inspirational advertising. In many advanced markets, people are more focused on their satisfaction or comfort than the opinion of others. We still concider traditional family values, but in the West such things are in the past - there are a lot of singles, people who meet their personal tastes and needs.

\section{Requirements for the brand under conditions of consumers' changing preferences}

A brand as a sociocultural phenomenon is purposefully created as cultural and symbolic object, functioning in te system of mass communications as a modified purposeful image. Distinct features of the brand are built around semantic core and position basic values of the subject of communication (Velitchenko, 2014).

The life cycle of a popular brand that has a rich history of its development, the popularity and recognition, can have quite a long period of existence, because it always has its supporters who do not betray their will. That is the last stage of the wine brand life cycle that can take a long time as there is a product that is in demand and occupies a certain niche in the market. New brands that appear and are promoted intensely, using modern marketing technologies to advertise new products, are often not quite perfect and can not always meet love and support from consumers, reducing thus the product life cycle and accordingly the life cycle of its brand (Pustotin, 2015).

So the producer should track the commodity market, tastes and wishes of consumers, that must be taken into account in the new requirements for the product and, therefore, be reflected in the ways of promotion and improvement of the brand itself (fig. 2).

Dynamic changes in the consumer market, increasing of competition require an appropriate instantaneous reaction of manufacturers and distributors of products to the external and internal challenges. In the face of declining demand for the products it is necessary to identify the factors that lead to this condition and offer the market updated high quality products with appropriate marketing accompaniment with its main effective tool, which is the brand.

\section{Social and ethical features of the wine brand}

The brand, which is focused on social responsibility reflects a centuries-old culture of wine production, brings the necessary knowledge, related not only to wine, but also to the tradition, art, promoting a healthy lifestyle. So the brand is not just profitable, but also performs this or that particular social work. And the consumer makes an informed choice in the favor of a brand, supporting one or another project. Global brands are really irreplaceable cultural and social elements (Saveliev, 2014). Many manufacturers have no clearly prescribed long-term strategy to create and promote the brand and are engaged in unconscious waste from the budget into image advertising, a logo, leaflets and so on. Thus the brand needs to be managed, especially because it affects all key indicators of production.

Buyers prefer brands, primarily influenced with emotional factors. A good brand promotes certain types of

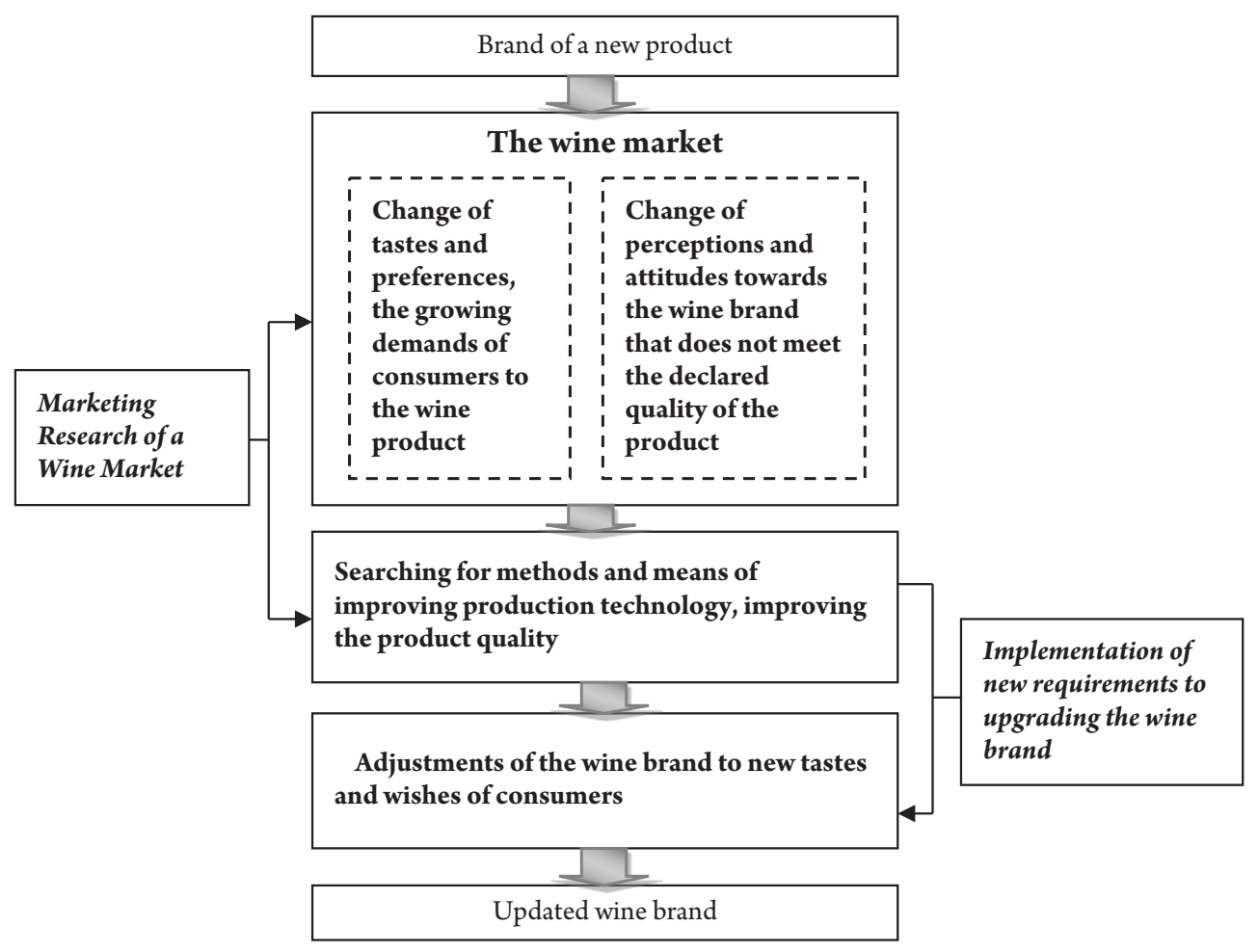

Fig. 2. The background of creation of the new wine brand 
social relationships. One of the components of the brand success is well-coordinated teamwork and commitment to continuous improvement and innovation. Doing wine business is limited with a huge number of various framework related to the perception of centuries-old culture of wine, legislative restrictions, unforeseen emotional decisions of consumers. Foremost it is meant the need to develop the concept of sales and create the right brand image.

\section{Conclusions}

On the creation of the wine brand should work together financiers, marketers, analysts, strategists, artists, promotion and graphic designers, copywriters, architects. It is necessary to develop a system of visual identity of the brand, the original name and choose rather rational and informative style of communication. The strategy of creating and branding should contain a step algorithm and a set of tools that allow to move from spontaneous advertising campaigns to systematic brand management system, motivate employees and stimulate the growth of its popularity. The brand has always increases the value of the product, reduces the time for consumer's attraction and its entering new markets. Thus, the brand is the highest achievement of management strategies and marketing policy. After all, to gain and maintain the popularity of a certain product, it is necessary to individualize, to give associations and images to give it different characteristics. Only then the product will cause a strong commitment to itself, to ensure its expected income growth in the future.

\section{References}

Zozulov, A. (2004), Pisarenko NL Market positioning: how to begin building successful brands. - K. : Knowledge Press, 2004. - 199 p.

Jones, P. (2005) The role of advertising in the creation of strong brands / Under the editors John Philip Jones. Williams, 2005. $-496 \mathrm{p}$.

Aleshin, M. (2013) The phenomenon of loyalty for goods and brands. [Electronic resource]. - Retrieved from: http://adme.ru/.

Pyankova, O. (2012) Life cycle concept of the brand [Electronic resource]. - Retrieved from: http://dspace.nuft. edu.ua/jspui/bitstream/123456789/7222/1/1223.pdf

Pustotin, V. (2015) Brand management as a process. [Electronic resource]. - Retrieved from: http://innovations.com.ua/ua/articles/finance/19350/upravlinnya-brendom-yak-proces

Fedoriv, A. (2015) MARKETING-Ukrainian forum DYREKTOROV: 2015 [Electronic resource]. - Retrieved from: http://www.marketingforum.com.ua

Saveliev, V. (2014) Marketing b2b technology sales in crisis [Electronic resource]. - Retrieved from: http://www.advanter.ua/articles.php?articlesid=66

Velitchenko, S. (2014) PR - Technology country branding of Kazakhstan in the context of religious values knowledge-based society. [Electronic resource]. - Retrieved from: http://euroasia-science.ru/zhurnaly/40zhurnal-4/politicheskie-nauki/809-pr-tekhnologii-tranovogo-rendinga-kazakhstana-v-kontekste-dukhovnykhtsennostej-intellektualnogo-obshchestva

Dligach, A. (2011) 8 stories about brands. [Electronic resource]. - Retrieved from: http://www.advanter.ua/ articles.php?articlesid=59

Saveliev, V. (2011) Natural wines and strong brands. [Electronic resource]. - Retrieved from: http://www.advanter.ua/articles.php?articlesid=53

Fedoriv, A. (2013) One word for the brand. [Electronic resource]. - Retrieved from: http://innovations.com.ua/ua/articles/finance/18731/odne-slovo-dlya-brendu

Pustotin, V. (2015) Branding Leaders. [Electronic resource]. - Retrieved from: http://innovations.com.ua/ua/ articles/finance/19372/brending-dlya-lideriv

Trout, J. (2012) May 11, 2012 Brand Strategy: Repositioning Commodities [Electronic resource]. - Retrieved from: http://www.brandingstrategyinsider.com/jack-trout

\section{Виктория ПАЗЮК}

\section{ЖИЗНЕННЫЙ ЦИКЛ ВИННОГО БРЕНДА}

Аннотация. Целью работы является определение жизненного цикла винного бренда, разработка путей повышения его действенности на разных стадиях жизненного цикла. Научно обоснованное существования жизненного цикла бренда позволяет современным предприятиям усилить свои конкурентные позиции на рынке и воспользоваться приобретенными различиями для привлечения большего внимания со стороны потребителей. Методика. Исследования базируются на общенаучных методах исследования экономических явлений: диалектический, абстрактно-логический (при осуществлении теоретических обобщений к определению сущности понятия «жизненный цикл виновного бренда), научное абстрагирование, сравнение и систематизация (при исследовании факторов влияния на жизненный цикл виновного бренда и факторов, влияют на выбор продукции потребителями), статистический и проблемно-хронологический 
Vol. 1, No. 2, 2015

Baltic Journal of ECONOMic Studies

(при исследовании требований к бренду в условиях изменения предпочтений потребителей), логического обобщения (при определении социально-этических функций виновного бренда). Результаты. Определены стадии жизненного цикла винного бренда, которые учитывают его особенности, а также сформированы его социально-этические функции. Описаны требования к винному бренду в условиях изменения вкусов и предпочтений потребителей. Раскрыта специфика продвижения винного бренда в условиях усиливающейся конкуренции. Установленны предпосылки создания нового винного бренда. Практическое значение. Бренд всегда увеличивает ценность продукта и его выход на новые рынки, а так же сокращает время привлечения потребителя. С помощью бренда возможно обеспечить рост на падающем рынке; наращивание рыночной доли в условиях высокой конкуренции; выход на рынок с инновационной продукцией с целью формирования новой стратегии сбыта. Ведь чтобы завоевать и сохранить популярность определенного продукта, необходимо индивидуализировать его, наделить ассоциациями и образом, предоставить ему отличительные особенности. Только тогда продукт будет вызывать к себе стойкую приверженность и обеспечивать ожидаемую прибыль. Адекватной мгновенной реакцией производителей и реализаторов продукции на внешние и внутренние вызовы, в условиях динамических сдвигов на потребительском рынке и обострение конкуренции, является бренд. Значение/оригинальность. В современных научных трудах все больше актуальности набирают разработки, о существовании и определения особенностей жизненного цикла бренда. Но учитывая специфику винной отрасли, освещение этого вопроса в литературе требует постоянно новых и инновационных подходов к решению проблем эффективности виновного бренда. В статье исследуются и описываются факторы, влияющие на жизненный цикл винного бренда, управление которыми обеспечивает усиление конкурентных преимуществ на определенных его стадиях и позволяет продлить срок действия бренда в условиях усиления конкуренции. 